\title{
SPATIAL VARIABILITY IN GREENHOUSE GAS FLUXES OF A TEMPERATE FRESHWATER MARSH IN CHINA: EFFECTS OF SOIL MOISTURE, ANIMAL ACTIVITIES AND LAND USE
}

\author{
BAO, T. ${ }^{1,2}-$ ZHU, R. B. ${ }^{1 *}-$ WANG, Q. ${ }^{1}-$ FANG, Z. Y. ${ }^{1}-$ LI, B. K. ${ }^{1}-$ GAO, Y. S. ${ }^{1}-$ XU, H. ${ }^{3}$ \\ ${ }^{1}$ Anhui Province Key Laboratory of Polar Environment and Global Change, School of Earth \\ and Space Sciences, University of Science and Technology of China, Hefei 230036, China \\ ${ }^{2}$ Key Laboratory of Regional Climate-Environment for Temperate East Asia, Institute of \\ Atmospheric Physics, Chinese Academy of Sciences, Beijing 100029, China \\ ${ }^{3}$ State Key Laboratory of Soil and Sustainable Agriculture, Institute of Soil Science, Chinese \\ Academy of Sciences, Nanjing 210008, China \\ *Corresponding author \\ e-mail: zhurb@ustc.edu.cn; phone: +86-551-6360-6010; fax: +86-551-6360-6010 \\ (Received $7^{\text {th }}$ Sep 2019; accepted $4^{\text {th }}$ Dec 2019)
}

\begin{abstract}
The greenhouse gas $\left(\mathrm{CH}_{4}, \mathrm{~N}_{2} \mathrm{O}\right.$ and $\left.\mathrm{CO}_{2}\right)$ fluxes from Shengjin Lake Marsh (SLM) were in situ investigated at the undisturbed sites and the disturbed sites by animal colonization and human activities. Overall the $\mathrm{CH}_{4}$ emissions from the wet sites were one order of magnitude higher than those from the mesic or dry sites, whereas higher $\mathrm{N}_{2} \mathrm{O}$ emissions and net $\mathrm{CO}_{2}$ uptake occurred at dry sites rather than at mesic and wet sites. Soil moisture was the predominant factor controlling the spatial variability in marsh $\mathrm{CH}_{4}$ and $\mathrm{N}_{2} \mathrm{O}$ fluxes and NEE at undisturbed sites. Mean $\mathrm{CH}_{4}$ fluxes from migrating water bird and poultry active areas showed no statistically significant differences from the undisturbed sites, but their activities significantly increased $\mathrm{N}_{2} \mathrm{O}$ emissions and decreased marsh $\mathrm{CO}_{2}$ sink, with the highest $\mathrm{N}_{2} \mathrm{O}$ fluxes (mean $49.5 \pm 11.9 \mu \mathrm{g} \mathrm{N}_{2} \mathrm{O} \mathrm{m} \mathrm{m}^{-2} \mathrm{~h}^{-1}$ ) in poultry active areas. The conversion of the marsh into agricultural field and landfill did not significantly change $\mathrm{CH}_{4}$ and $\mathrm{N}_{2} \mathrm{O}$ fluxes, but significantly decreased $\mathrm{CO}_{2}$ sink. Our results revealed that the accurate evaluation of GHG budget for the SLM and other similar temperate wetlands should involve soil water regimes, water bird colonization and human-induced influences.
\end{abstract}

Keywords: $\mathrm{CH}_{4}$ flux, $\mathrm{N}_{2} \mathrm{O}$ flux, NEE, Shengjin Lake Marsh, temperate wetland

\section{Introduction}

Atmospheric carbon dioxide $\left(\mathrm{CO}_{2}\right)$, methane $\left(\mathrm{CH}_{4}\right)$ and nitrous oxide $\left(\mathrm{N}_{2} \mathrm{O}\right)$ are key radiatively active greenhouse gases (GHGs) (Ravishankara et al., 2009). Natural wetlands play a critical role in the global GHG budgets due to the storage of a large amount of carbon and nitrogen (Post et al., 1982), the high temperature sensitivity of microbial respiration, and nitrogen mineralization (Davidson and Janssens, 2006; Song et al., 2009). The wetlands are one of important sources for atmospheric GHGs (Jungkunst and Fiedler, 2007; Marani and Alvala, 2007; Song et al., 2009). For example, natural wetlands present the largest single $\mathrm{CH}_{4}$ source, accounting for more than $75 \%$ of natural $\mathrm{CH}_{4}$ source and more than $20 \%$ of the global $\mathrm{CH}_{4}$ source (Kirschke et al., 2013). Global wetland ecosystems also contribute considerably to $\mathrm{N}_{2} \mathrm{O}$ budget although sometimes the $\mathrm{N}_{2} \mathrm{O}$ emissions from the wetlands are very low (Martikainen et al., 1993; Xu et al., 2008). Therefore, it is necessary to conduct the research about GHG fluxes from the wetlands in different climatic zones. 
At present, net GHG fluxes have been extensively measured at a number of sites of global wetlands to better understand the relationships between GHG fluxes and environmental parameters (Jungkunst and Fiedler, 2007; Marani and Alvala, 2007; Song et al., 2009). China is home to the world's fourth largest wetland area (Wang et al., 2012), and in situ GHG flux observations have covered the wetlands in Northeast China (Ding et al., 2004; Ding and Cai, 2007; Song et al., 2009), the Tibetan Plateau (Chen et al., 2008; Song et al., 2015; Wei et al., 2015), Inner Mongolia (Duan et al., 2005; Wang et al., 2009), coastal salt marshes (Song and Liu, 2016), and the Middle-Lower Yangtze Floodplain (MLYP) wetlands including the freshwater marshes in Poyang Lake and Taihu Lake (Xing et al., 2005; Wang et al., 2006; Hu et al., 2016). Observations suggest that the wetlands showed the micro- and macro-scale spatial pattern of GHG release (Kato et al., 2011; Song and Liu, 2016; Wei and Wang, 2017), and soil physicochemical properties, soil microbial community structure, vegetation coverage and warming climate are important factors affecting wetland GHG fluxes (Johansson et al., 2006; Wei and Wang, 2017). The MLYP is characterized by dense human population and rapid economic development, which both impose unprecedented pressure on the wetland ecosystems, and has caused serious wetland degradation (Zhou et al., 2010). In addition, the MLYP wetland is an important wintering habitat and stopover site for migrating waterbirds on the East Asia-Australia Flyway (Fang et al., 2006). Environmental variables, animal colonization and human activities might lead to spatial variability in GHG emissions from the MLYP wetland. A better understanding of the spatial patterns in the GHG fluxes and their controlling factors is crucial to accurately estimate the regional and global GHG budgets from wetlands (Song et al., 2009; Kirschke et al., 2013; Wei and Wang, 2017). Nevertheless, the data about GHG fluxes are still lacking in the MLYP wetlands, and especially effects of animal colonization and human activities on GHG fluxes are highly neglected.

The Shengjin Lake Marsh (SLM), as a natural freshwater wetland, is located in the MLYP with temperate monsoon climate and an evident distinction between rainy and dry seasons in the precipitation. Part of the marsh is often converted into farmlands including paddy fields or wheat lands with the drawdown of water level. This marsh also provides an important natural colony for some migrant waterbirds to overwinter and breed, and a natural raising area for the poultry including ducks and gooses (Lu and Liu, 2011). The natural disturbances due to flood and drought, animal colonization and human activities have intensively affected the local environment (Yang et al., 2015). However, effects of these natural and anthropogenic factors on GHG fluxes to date have not been investigated in the SLM. During summer and winter in 2013, the SLM was selected as study area, and $\mathrm{CH}_{4}, \mathrm{~N}_{2} \mathrm{O}$ and $\mathrm{CO}_{2}$ fluxes were simultaneously observed at the upland and lowland marsh areas, and the marsh sites disturbed by animal colonization and land use. Our objectives were (1) to study spatial variability in GHG fluxes from the marsh; (2) to investigate the effects of soil moisture on GHG fluxes; (3) to examine the effects of animal activities and land use on GHG fluxes. This is an important attempt to reasonably evaluate the importance of soil moisture, animal activities and land use in the GHG budgets in the MLYP wetland. 


\section{Materials and methods}

\section{Study area}

The Shengjin Lake Wetland National Nature Reserve $\left(116^{\circ} 55^{\prime}\right.$ E- $117^{\circ} 15^{\prime}$ E, $30^{\circ} 15^{\prime}$ $\mathrm{N}-30^{\circ} 30^{\prime} \mathrm{N}$ ) is located in the Middle-Lower Yangtze Plain (Fig. 1). The wetland covers an area of approximately $133 \mathrm{~km}^{2}$ in the rain season and only $33 \mathrm{~km}^{2}$ in the dry season. This area has a temperate monsoon climate with a hot and humid summer, and a cold and dry winter; its mean annual air temperature and precipitation is about $16.1^{\circ} \mathrm{C}$ and about $1600 \mathrm{~mm}$, respectively (Xu et al., 2008). Topographically the Shengjin Lake can be divided into three parts: the upper lake, the middle lake and the lower lake. The marsh around the lake has diverse vegetation types including Artemisia lavandulaefolia DC, Artemisia scoparia waldst and Pinus massoniana (Lu and Liu, 2011; Yang et al., 2015). It is a natural colony for over 100 species of migratory birds to overwinter and breed (Lu and Liu, 2011). The common species of waterbirds include bean goose Anser fabialis, greater white-fronted goose Anser albifrons, lesser white-fronted goose Anser erythropus, swan goose Anser cygnoides and tundra swan Cygnus columbianus bewickii (Zhang et al., 2015). Overall the Shengjin Lake Marsh (SLM) has been experiencing the disturbance from human activities, poultry raising and natural disturbances from waterbirds, drought and flooding (Jiang et al., 2007; Lu and Liu, 2011; Fox et al., 2013).

More information was given in S1 for Electronic Appendix.

(a)

(c)

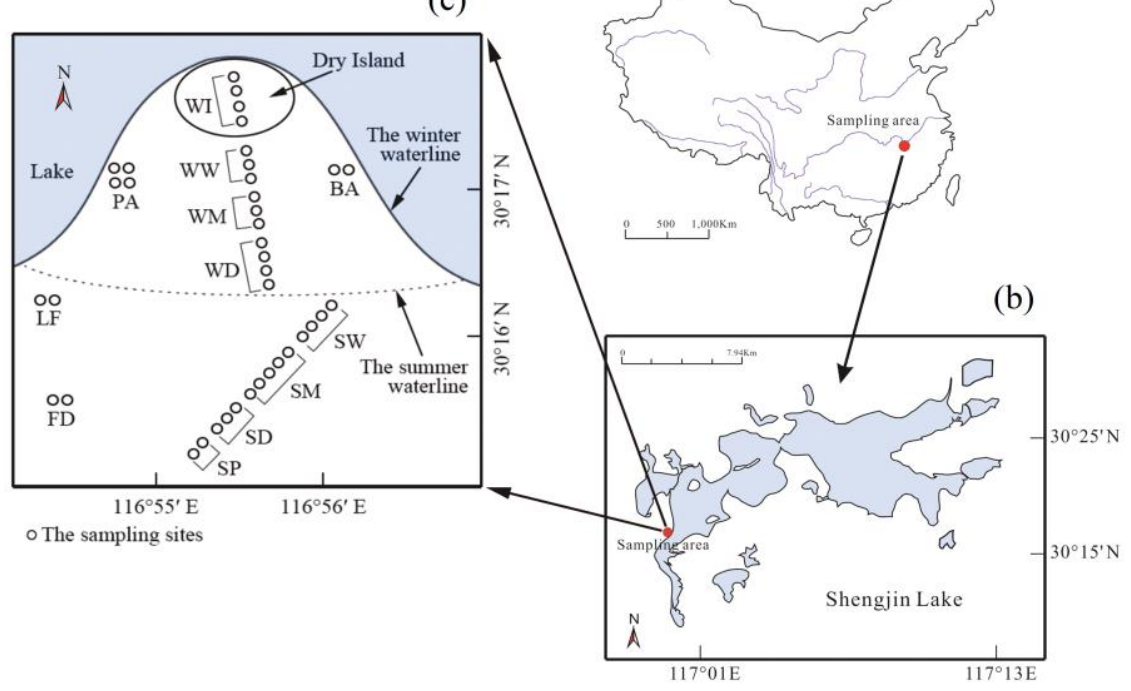

Figure 1. (a) The red dot indicates location of the investigation area in China. (b) The topographic feature of Shengjin Lake and the red dot indicates location of the investigation area in Shengjin Lake. (c) The location of the investigation sites for the SLM in the summer and winter. SD, SM, SW and SP represent the dry, mesic and wet marsh sites, and paddy field sites in the summer, respectively; WD, WM, WW and WI represent the dry, mesic and wet marsh sites, and the island marsh sites, respectively, in the winter; $B A, P A, L F$ and FD represents water bird active area, poultry active area, landfill and farmland, respectively. In the summer, the lake water level rose up to the highest, and the marsh formed along the summer waterline. In the winter, a large flooded land area was exposed with the decrease in the lake water level and the marsh formed along the winter waterline 


\section{Investigation sites and experimental design}

To test effects of soil moisture, waterbird colonization and human activities on the spatial variability in GHG fluxes from the SLM, a series of the flux observation sites were established within the following three areas located on the western shore of the upper lake as illustrated in Fig. 1:

(i) The upland marsh area: In summer, the lake water level rises up to the highest along the shore. In July 2013 (From July $1^{\text {st }}$ to July $30^{\text {th }}$ ), a total of 14 stations (sj1-1 to sj1-14) for summer GHG flux observations were set up from the wet to dry marsh areas along a transect. These stations were further divided into four types of sites according to soil water regime: (a) wet site (SW), which were near the lake with almost no vegetation; (b) mesic site (SM) with few vegetation; (c) dry site (SD) with the extensive vegetation; and (d) paddy site (SP), which was located at the uppermost locality of the transect with changing water levels. Two repetitions of GHG flux measurements were made at each station.

(ii) The lowland marsh area: A large flooded land area was exposed in winter with the drawdown of water level. In December 2013 (From December $1^{\text {st }}$ to December $30^{\text {th }}$ ), we selected a long transect from the upland to the lowland, and then to a small island along the shore. A total of 14 stations (sj2-1 to sj2-14) along the transect were set up for GHG flux measurements. These stations were divided into four types of sites as follows: (a) dry marsh site (WD); (b) mesic marsh site (WM); (c) wet marsh site (WW); (d) dry island marsh site (WI). Two repetitions were made at each station.

(iii) The marsh sites disturbed by animal activities and land use: In December 2013, a total of 10 stations were set up in the disturbed areas for GHG flux measurements. These stations were divided into four types of sites: waterbird active site (BA, two stations), poultry active site (PA, four stations), landfill (LF, two stations) and farmland (FD, two stations). Two repetitions were made at each station. In Electronic Appendix, more detailed information was given in $S 2$, and soil physiochemical properties at all the stations were summarized in Table S1 and Table S2.

\section{In-situ GHG flux measurements}

The GHG fluxes from all the stations were measured in the SLM during two sampling campaigns (July, 2013 in the summer, and December, 2013 in the winter) using a static chamber technique (Hutchinson and Mosier, 1981; Zhu et al., 2014a,b). Open-bottomed clear plexiglass chambers $(50 \mathrm{~cm} \times 50 \mathrm{~cm} \times 50 \mathrm{~cm})$ were placed on the PVC collars installed at the measurement sites. The collars enclosed an area of about $0.25 \mathrm{~m}^{2}$ and were inserted into the soils to a depth of about $5 \mathrm{~cm}$. The use of flux collars ensures that flux chambers are well sealed since the chambers fit into a water-filled notch in the collars. The average chamber height was $45 \mathrm{~cm}$ above the ground, which met the minimum required without influencing gas diffusion patterns under normal atmospheric pressure (Hutchinson and Mosier, 1981).

During gas flux measurements, upon enclosure of the cover chambers, headspace gas samples were collected at $0,10,20$ and 30 min intervals with a double ended needle connected to pre-vacuated glass vials $(18 \mathrm{~mL})$ with butyl rubber septa. For each gas flux measurement, a total of four samples were withdrawn from each chamber after enclosure. Internal air temperature inside the chambers was simultaneously measured using a thermometer installed on the chamber. Ground temperature (GT) and soil moisture $(\mathrm{Mc})$ were measured before and after the gas sampling. The order of 
measurements was varied to ensure that the measuring time did not bias the results, resulting in two replicate measurements per station.

Net ecosystem exchange (NEE), defined as net ecosystem $\mathrm{CO}_{2}$ flux under light conditions, was measured by the change in $\mathrm{CO}_{2}$ concentrations in transparent chambers (Ström et al., 2007). In summer 2013, immediately following NEE measurements, ecosystem respiration (ER) was measured by the same procedure after darkening of the chamber covered by three layers of thick black cloth. Marsh ER includes soil and vegetation respiration, and photosynthesis was calculated as the difference between NEE and dark respiration (Ström et al., 2007).

\section{Determination of GHG concentrations and flux calculation}

The methods of analyzing GHG concentrations and flux calculation are described in detail in our previous papers (Zhu et al., 2014a,b; Bao et al., 2018a,b). In brief, $\mathrm{N}_{2} \mathrm{O}$, $\mathrm{CH}_{4}$ and $\mathrm{CO}_{2}$ concentrations were analyzed using gas chromatography equipped with a ${ }^{63} \mathrm{Ni}$ electron capture detector, a flame ionization detector and a thermal conductivity detector, respectively (GC-HP5890 II, USA; Shimadzu GC-12A, Japan; Shimadzu GC-14B, Japan). Net GHG fluxes were calculated using a linear least squares fit to four points in the time series of concentrations with an average chamber temperature. The least squares regression lines "headspace GHG concentrations versus time" were first visually inspected for abrupt changes in the direction of the flux, resulting from disturbances such as the leakage of the chamber or disturbances of soils during sampling. The correlation coefficient $\mathrm{R}^{2}>0.95$ for linear regression was used as a quality check for the measurement. If the fluxes are low, the random error of the measurement can be larger than the change in GHG concentrations between two sampling points. Discarding these fluxes based on low $\mathrm{R}^{2}$ values would lead to an overestimation of the overall fluxes. Some low fluxes were included regardless of their $\mathrm{R}^{2}$ values. For the gas fluxes, positive values indicate net emission to the atmosphere, and negative values indicate net uptake from the atmosphere. More information was given in S3 for Electronic Appendix.

\section{Environmental variables and general soil properties}

Altogether 41 soil samples ( 3 samples were taken at each station except sj1-1 only 2 samples) in summer and 48 soil samples (2 samples were taken at each station) in winter were taken along with the same stations where GHG fluxes were measured. All the soil samples were air-dried, milled and screened using the 200 mesh sifter for the detection. Soil gravimetric moisture content $\left(\mathrm{M}_{\mathrm{C}}\right)$ was determined by drying the soil at $105^{\circ} \mathrm{C}$ for $12 \mathrm{~h}$. $\mathrm{M}_{\mathrm{C}}$ was calculated as: $\mathrm{M}_{\mathrm{C}}=$ the weight of the lost water/dry soil weight $\times 100 \%$. The $\mathrm{pH}$ was determined in distilled water and in $1 \mathrm{M} \mathrm{KCl}$ solution (soil: solution ratio $=1: 3$ ). Total organic carbon $(\mathrm{TOC})$ was analyzed from the dry soil by the potassium dichromate volumetric method with an analytic error of $2.5 \%$. Total carbon (TC), total nitrogen (TN) and total sulfur (TS) were determined using vario MACRO CHNS analyzer. The $\mathrm{NH}_{4}{ }^{+}-\mathrm{N}$ and $\mathrm{NO}_{3}^{-}-\mathrm{N}$ were determined by an ion-selective electrode method with an analytical error of $<5.0 \%$, and total phosphorus (TP) was determined by ultraviolet visible spectrometry (UV-2450, Shimadzu, Japan) with an analytical error of $<2.0 \%$ (Zhu et al., 2009). 


\section{Statistical analysis}

Microsoft Excel 2013 and SPSS 20.0 are used to make the statistical analysis of the data under the Windows 10 environment. For each station, we used standard error (SE) to estimate the uncertainty of the individual fluxes. The individual fluxes and their associated uncertainty were then averaged for each type of marsh site. All the data for GHG fluxes were expressed as mean $\pm \mathrm{SE}$. We used the coefficient of variance $(\mathrm{CV})$ of those flux as a measure of intra-site spatial variability. The statistically significant differences between the means for each type of sites in the upland, lowland and disturbed marsh areas were tested using Fisher's Least Significant Difference (LSD, $\mathrm{P}<0.05)$ tests. We used the Principal Component Analysis (PCA) as a multivariate exploratory technique to explain the main factors affecting spatial variability in GHG emissions at the undisturbed and disturbed sites. To find factors causing spatial variability in the fluxes, the correlations of GHG fluxes with environmental variables were tested separately for all the types of sites using Spearman's rank order correlation. A univariate exponential function model (Eq.l) was fitted for the relationship between ER and soil temperature:

$$
E R=\beta_{0} \mathrm{e}^{\beta_{1} T}
$$

where ER is ecosystem respiration $\left(\mathrm{mg} \mathrm{CO} \mathrm{CO}_{2}^{-2} \mathrm{~h}^{-1}\right)$, $\mathrm{T}$ is mean soil temperature $\left({ }^{\circ} \mathrm{C}\right)$, and $\beta_{0}$ and $\beta_{1}$ are the constants fitted with the least squares technique. The $Q_{10}$ value was calculated as (Eq.2):

$$
Q_{10}=\mathrm{e}^{10 \beta_{1}}
$$

In all analyses where $\mathrm{p}<0.05$, the factor tested and the relationship were considered statistically significant. Although our data might represent a rough estimate of GHG fluxes, we still used the GWP (Global Warming Potential) as a conversion factor to evaluate the impact of the SLM on the greenhouse effect. Based on a 100-year time frame, the GWPs of $\mathrm{CH}_{4}$ and $\mathrm{N}_{2} \mathrm{O}$ are, respectively, 25 and 298 times higher than that of $\mathrm{CO}_{2}$ (Ravishankara et al., 2009). The net GWP were calculated by taking mass factors, 1 for $\mathrm{CO}_{2}, 25$ for $\mathrm{CH}_{4}$, and 298 for $\mathrm{N}_{2} \mathrm{O}$.

\section{Results}

\section{Environmental variables in the marsh}

The soils at the upland marsh transect were slightly acid with the $\mathrm{pH}$ of 5.2-6.1, and soil moisture decreased from the lowland to the upland marsh with the range of 17\%-59\% (Table S1 and Table S2). Ground temperatures showed no significant differences between four types of sites in summer or in winter (Fig. 2). TC, TOC and TN levels in the soils showed no significant differences. The TC and TOC levels were very close to each other (average $1.24 \%$ and $1.13 \%$ ), and they showed a significant correlation $(\mathrm{R}=0.941)$, indicating that soil carbon in the marsh mainly existed as organic carbon. Soil organic carbon content (average 2.62\%) at the lowland marsh was almost twice higher than that at the upland marsh (average 1.13\%). Soil $\mathrm{NO}_{3}{ }^{-}-\mathrm{N}$ contents were one to two orders of magnitude higher than $\mathrm{NH}_{4}{ }^{+}-\mathrm{N}$ contents at upland or lowland 
marsh transects. Soil $\mathrm{NO}_{3}{ }^{-} \mathrm{N}$ contents in landfill, poultry and waterbird active areas and farmland were evidently higher than those in non-disturbed marsh areas, and extremely high $\mathrm{NO}_{3}{ }^{-}-\mathrm{N}$ occurred in poultry active soils $\left(1143.4 \mu \mathrm{g} \mathrm{g}^{-1}\right)$. In addition, soil moisture showed evident differences with the range of 19\%-73\% between the types of marsh sites due to effects of animal activities and land use.
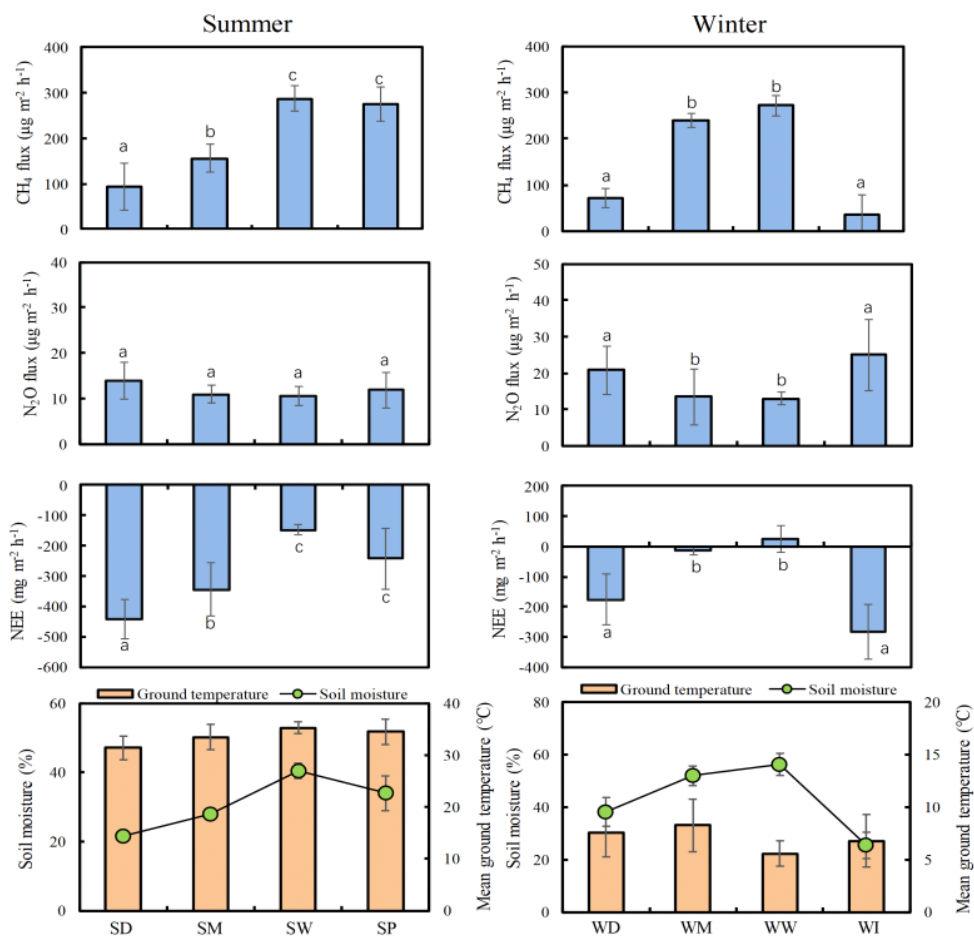

Figure 2. Spatial variability in $\mathrm{CH}_{4}, \mathrm{~N}_{2} \mathrm{O}$ and $\mathrm{CO}_{2}$ fluxes from the SLM transects during the summer and winter. The given data are the mean values at each site in the marsh, and the vertical bars indicate standard errors of GHG fluxes. (a) In the summer, $S D(n=6), S M(n=10)$,

$S W(n=8)$ and $S P(n=4)$ represent the dry, mesic and wet marsh sites, and paddy field sites, respectively; (b) In the wintertime, WD $(n=8), W M(n=6), W W(n=6)$ and $W I(n=8)$ represent

the dry, mesic and wet marsh sites, and the island marsh sites, respectively. The different lowercase letters $(a, b, c)$ indicate statistically significant differences between the mean values (Fisher's LSD, $P<0.05$ )

\section{$\mathrm{CH}_{4}$ fluxes}

The wet marsh sites SW and WW showed strong $\mathrm{CH}_{4}$ emissions with the mean fluxes of 287.3 $\pm 51.1 \mu \mathrm{g} \mathrm{CH}_{4} \mathrm{~m}^{-2} \mathrm{~h}^{-1}$, and 271.2 $\pm 21.1 \mu \mathrm{g} \mathrm{CH}_{4} \mathrm{~m}^{-2} \mathrm{~h}^{-1}$, respectively. Dry marsh sites SD and WD showed net weak $\mathrm{CH}_{4}$ emissions with the mean rates of 93.9 $\pm 27.8 \mu \mathrm{g} \mathrm{CH}_{4} \mathrm{~m}^{-2} \mathrm{~h}^{-1}$ and $70.1 \pm 20.7 \mu \mathrm{g} \mathrm{CH}_{4} \mathrm{~m}^{-2} \mathrm{~h}^{-1}$, one order of magnitude lower than those from the mesic and wet sites, whereas the lowest $\mathrm{CH}_{4}$ emission occurred at the dry island site WI (Fig. 2). The paddy site SP showed strong $\mathrm{CH}_{4}$ emission $\left(275.8 \pm 37.7 \mu \mathrm{g} \mathrm{CH}_{4} \mathrm{~m}^{-2} \mathrm{~h}^{-1}\right)$, comparable to the sites $\mathrm{SW}$ and $\mathrm{WW}$, but significantly higher than those at the sites SM and SD (Table 1). Overall the fluxes from waterbird active area $\left(148.3 \pm 51.5 \mu \mathrm{g} \mathrm{CH}_{4} \mathrm{~m}^{-2} \mathrm{~h}^{-1}\right)$ and landfill $\left(98.8 \pm 28.9 \mu \mathrm{g} \mathrm{CH}_{4} \mathrm{~m}^{-2} \mathrm{~h}^{-1}\right)$ were higher than those from poultry active area $\left(64.4 \pm 44.3 \mu \mathrm{g} \mathrm{CH}_{4} \mathrm{~m}^{-2} \mathrm{~h}^{-1}\right)$ and farmland $\left(20.0 \pm 105.0 \mu \mathrm{g} \mathrm{CH}_{4} \mathrm{~m}^{-2} \mathrm{~h}^{-1}\right)$ although their mean fluxes showed no statistical significant differences (Fig. 3). 
Table 1. Comparisons of $\mathrm{CH}_{4}, \mathrm{~N}_{2} \mathrm{O}$ and $\mathrm{CO}_{2}$ fluxes at the different types of sites in Shengjin Lake Marsh

\begin{tabular}{|c|c|c|c|c|c|c|c|c|c|c|c|c|}
\hline \multirow{2}{*}{$\begin{array}{c}\text { Marsh site } \\
\text { types }\end{array}$} & \multicolumn{3}{|c|}{$\mathrm{CH}_{4}$ flux $\left(\mu \mathrm{CH}_{4} \mathrm{~m}^{-2} \mathrm{~h}^{-1}\right)$} & \multicolumn{3}{|c|}{$\mathrm{N}_{2} \mathrm{O}$ flux $\left(\mu \mathrm{g} \mathrm{N}_{2} \mathrm{O} \mathrm{m}^{-2} \mathrm{~h}^{-1}\right)$} & \multicolumn{3}{|c|}{$\mathrm{NEE}\left(\mathrm{mg} \mathrm{CO} \mathrm{Cm}^{-2} \mathrm{~h}^{-1}\right)$} & \multicolumn{3}{|c|}{$\mathrm{ER}\left(\mathrm{mg} \mathrm{CO} \mathrm{Cm}^{-2} \mathrm{~h}^{-1}\right)$} \\
\hline & Range & Mean $\pm \mathbf{S E}$ & CV $(\%)$ & Range & Mean $\pm \mathbf{S E}$ & CV $(\%)$ & Range & Mean \pm SE & CV $(\%)$ & Range & Mean $\pm \mathbf{S E}$ & CV $(\%)$ \\
\hline \multicolumn{13}{|c|}{ Summertime, July, 2013} \\
\hline SW & $152.0-773.0$ & $287.3 \pm 51.1 \mathrm{a}$ & 17.8 & $1.5-18.3$ & $10.6 \pm 4.1 \mathrm{a}$ & 38.7 & $-270.6-28.3$ & $-148.5 \pm 65.0 \mathrm{a}$ & 43.8 & 218.9-1531.9 & $694.2 \pm 420.1 \mathrm{a}$ & 60.5 \\
\hline SM & $10.2-399.8$ & $155.9 \pm 31.5 \mathrm{~b}$ & 20.2 & $6.4-16.5$ & $11.0 \pm 2.0 \mathrm{a}$ & 18.2 & -552.5 to -42.6 & $-345.9 \pm 88.1 b$ & 25.5 & $15.7-1132.9$ & $674.9 \pm 210.8 \mathrm{a}$ & 31.2 \\
\hline SD & $62.6-149.3$ & $93.9 \pm 27.8 \mathrm{c}$ & 29.6 & $10.3-17.7$ & $13.9 \pm 2.1 \mathrm{a}$ & 15.1 & -473.8 to -415.0 & $-443.6 \pm 17.0 \mathrm{c}$ & 3.8 & $926.9-1305.5$ & $1106.9 \pm 109.7 \mathrm{~b}$ & 9.9 \\
\hline SP & $139.6-412.0$ & $275.8 \pm 37.7 \mathrm{a}$ & 13.7 & $8.1-15.7$ & $11.9 \pm 3.8 \mathrm{a}$ & 31.9 & -472.2 to -12.8 & $-242.5 \pm 101.2 \mathrm{a}$ & 41.7 & $887.2-1200.1$ & $1043.7 \pm 156.5 b$ & 15.0 \\
\hline Comprehensive & $10.2-773.0$ & $197.3 \pm 205.5$ & 104.2 & $1.5-18.3$ & $11.6 \pm 4.9$ & 42.2 & $-552.5-28.3$ & $-295.7 \pm 192.9$ & 65.2 & $15.7-1305.5$ & $835.8 \pm 446.1$ & 53.4 \\
\hline \multicolumn{13}{|c|}{ Wintertime, December, 2013} \\
\hline WW & $127.4-403.8$ & $271.2 \pm 21.1 \mathrm{~b}$ & 7.8 & $10.2-16.2$ & $13.0 \pm 1.7 \mathrm{~b}$ & 13.1 & -406.0 to -104.2 & $-24.1 \pm 43.8 b$ & 1.8 & & & \\
\hline WM & $212.3-265.5$ & $240.3 \pm 15.4 \mathrm{~b}$ & 6.4 & $-1.8-21.9$ & $13.4 \pm 7.6 \mathrm{~b}$ & 56.7 & $-39.4-8.5$ & $-14.5 \pm 13.9 b$ & 96.0 & & & \\
\hline WD & 20.9-110.5 & $70.1 \pm 20.7 \mathrm{a}$ & 29.5 & $9.8-38.0$ & $20.8 \pm 6.7 \mathrm{a}$ & 32.2 & $-323.8-48.8$ & $-176.1 \pm 84.2 \mathrm{a}$ & 47.8 & & & \\
\hline WI & $-35.5-104.8$ & $36.4 \pm 40.5 \mathrm{a}$ & 111.3 & $14.1-35.2$ & $25.1 \pm 9.8 \mathrm{a}$ & 39.0 & $-44.3-151.5$ & $-284.7 \pm 90.1 \mathrm{a}$ & 31.6 & & & \\
\hline Comprehensive & $-35.5-403.8$ & $108.3 \pm 191.1$ & 176.5 & $-1.8-38.0$ & $18.8 \pm 10.9$ & 58.0 & $-406.0-151.5$ & $-129.6 \pm 173.0$ & 133.5 & & & \\
\hline
\end{tabular}

The measured GHG fluxes at marsh site types with the same suffix letter ( $\mathrm{a}, \mathrm{b}$ or $\mathrm{c}$ ) are not significantly different from one another (LSD, P<0.05). Marsh ER was not observed in 2013 winter 


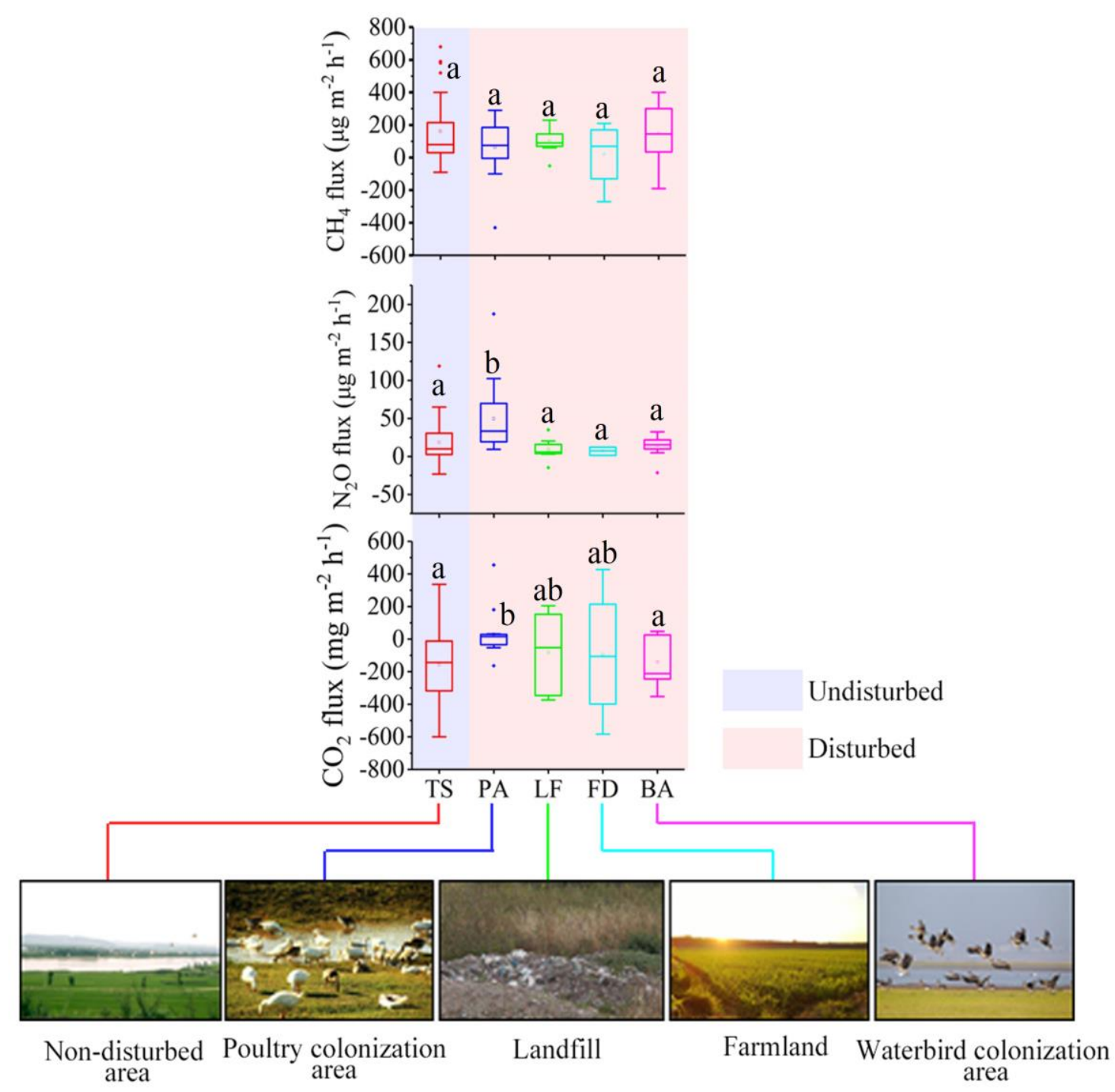

Figure 3. Comparisons of $\mathrm{CH}_{4}, \mathrm{~N}_{2} \mathrm{O}$ and $\mathrm{CO}_{2}$ fluxes from different non-disturbed and disturbed marsh areas. $T S(n=56), P A(n=8), L F(n=4), F D(n=4)$ and $B A(n=4)$ represent non-disturbed site, poultry colonization area, landfill, farmland, and waterbird colonization area, respectively.

The different lowercase letters $(a, b)$ indicate statistically significant differences between the mean fluxes (Fisher's LSD, $P<0.05$ )

The PCA analysis showed that the environmental variables in the first two components explained $71.0 \%$ and $87.2 \%$ of the cumulative variance of the $\mathrm{CH}_{4}$ fluxes at the undisturbed and disturbed marsh sites, respectively, and soil moisture was the predominant factor affecting spatial variability in $\mathrm{CH}_{4}$ emission (Fig. 4). The $\mathrm{CH}_{4}$ fluxes showed a significant positive correlation with soil moisture at the undisturbed or disturbed marsh sites. When the data at all the observation sites were combined, $\mathrm{CH}_{4}$ fluxes showed a strong positive correlation $(\mathrm{P}=0.000)$ with soil moisture (Table 2$)$. The $\mathrm{TN}, \mathrm{NH}_{4}{ }^{+}-\mathrm{N}$ did not significantly affect $\mathrm{CH}_{4}$ emissions at the undisturbed sites, whereas they showed a significant positive correlation with $\mathrm{CH}_{4}$ emissions at the disturbed marsh sites. 
(a)

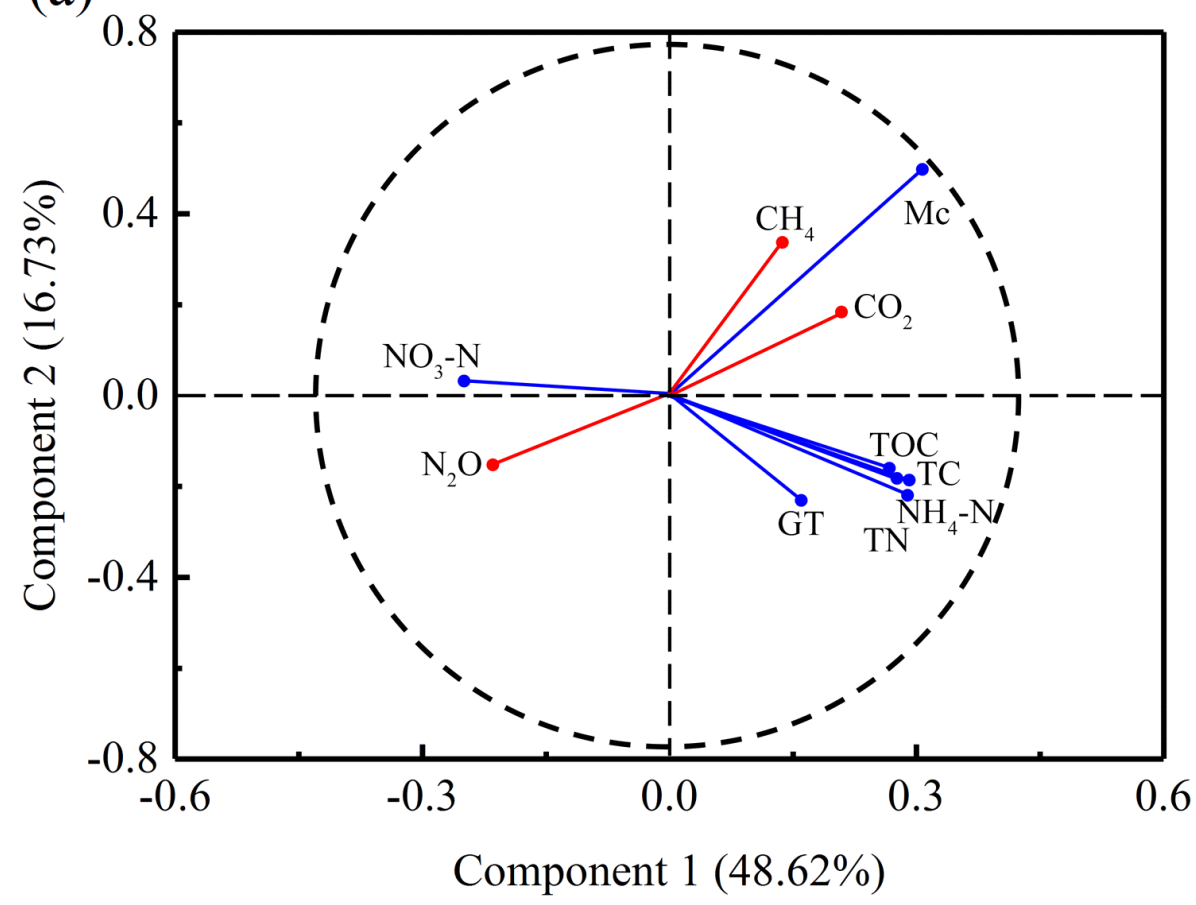

(b)

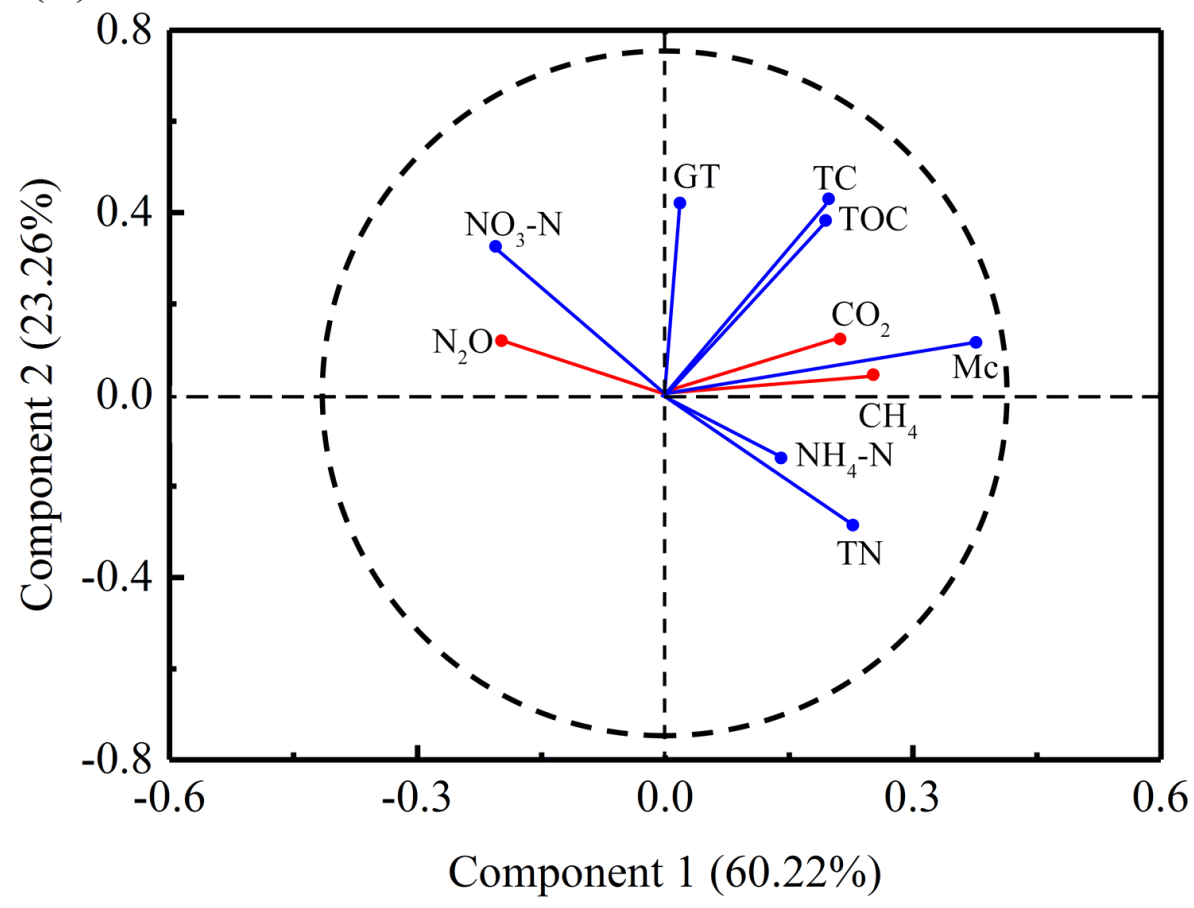

Figure 4. Correlation bi-plot between GHG fluxes and environmental variables in nondisturbed (a) and disturbed (b) marsh areas based upon the standardized principal component analysis. The first two dimensions explained $65 \%$ and $83 \%$ of the variation for non-disturbed and disturbed marsh areas, respectively. Mc, TOC, TN, TC and GT indicate soil moisture, total organic carbon, total nitrogen, total carbon and ground temperature, respectively 
Table 2. Correlations between marsh greenhouse gas fluxes and environmental parameters during the observation period. Significant statistics $(P<0.05)$ are highlighted in bold type

\begin{tabular}{|c|c|c|c|c|c|c|c|c|c|}
\hline & \multicolumn{3}{|c|}{ Undisturbed marsh sites $(n=69)$} & \multicolumn{3}{|c|}{ Disturbed marsh sites $(\mathrm{n}=20)$} & \multicolumn{3}{|c|}{ Overall $(n=89)$} \\
\hline & $\begin{array}{c}\mathrm{CH}_{4} \text { Flux } \\
\left(\mu \mathrm{g} \mathrm{CH} \mathbf{C H}_{4} \mathbf{m}^{-2} \mathbf{h}^{-1}\right) \\
\end{array}$ & $\begin{array}{c}\mathbf{N}_{2} \mathrm{O} \text { Flux } \\
\left(\mu \mathrm{g} \mathbf{N}_{2} \mathrm{O} \mathrm{m}^{-2} h^{-1}\right)\end{array}$ & $\begin{array}{c}\mathrm{CO}_{2} \text { Flux } \\
\left(\mathrm{mg} \mathrm{CO}_{2} \mathbf{~ m}^{-2} \mathbf{h}^{-1}\right)\end{array}$ & $\begin{array}{c}\mathrm{CH}_{4} \text { Flux } \\
\left(\mu \mathrm{g} \mathrm{CH}_{4} \mathbf{m}^{-2} \mathbf{h}^{-1}\right) \\
\end{array}$ & \begin{tabular}{c|c|}
$\mathbf{N}_{2} \mathrm{O}$ Flux \\
$\left(\mu \mathrm{g} \mathrm{N} \mathbf{N}_{2} \mathrm{O} \mathrm{m}^{-2} \mathbf{h}^{-1}\right)$ \\
\end{tabular} & $\begin{array}{c}\mathrm{CO}_{2} \text { Flux } \\
\left(\mathrm{mg} \mathrm{CO}_{2} \mathbf{m}^{-2} \mathbf{h}^{-1}\right)\end{array}$ & \begin{tabular}{c|c|}
$\mathrm{CH}_{4}$ Flux \\
$\left(\mu \mathrm{g} \mathrm{CH} \mathbf{~ m}^{-2} \mathbf{h}^{-1}\right)$ \\
\end{tabular} & \begin{tabular}{|c|}
$\mathrm{N}_{2} \mathrm{O}$ Flux \\
$\left(\mu \mathrm{g} \mathbf{N}_{2} \mathrm{O} \mathbf{m}^{-2} \mathbf{h}^{-1}\right)$ \\
\end{tabular} & $\begin{array}{c}\mathrm{CO}_{2} \text { Flux } \\
\left(\mathrm{mg} \mathrm{CO}_{2} \mathbf{m}^{-2} \mathbf{h}^{-1}\right) \\
\end{array}$ \\
\hline \multirow{2}{*}{ Mc (\%) } & 0.449 & -0.656 & 0.258 & 0.556 & -0.578 & 0.501 & 0.641 & -0.704 & 0.244 \\
\hline & $P=0.000$ & $\mathbf{P}=\mathbf{0 . 0 0 0}$ & $\mathbf{P}=\mathbf{0 . 0 3 2}$ & $P=0.011$ & $P=0.008$ & $\mathbf{P}=\mathbf{0 . 0 2 5}$ & $\mathbf{P}=\mathbf{0 . 0 0 0}$ & $\mathbf{P}=\mathbf{0 . 0 0 0}$ & $P=0.021$ \\
\hline \multirow{2}{*}{ TOC (\%) } & 0.053 & -0.190 & 0.190 & 0.065 & -0.449 & 0.171 & 0.074 & -0.254 & 0.114 \\
\hline & $\mathrm{P}=0.664$ & $\mathrm{P}=0.235$ & $\mathrm{P}=0.235$ & $\mathrm{P}=0.787$ & $P=0.047$ & $\mathrm{P}=0.472$ & $\mathrm{P}=0.492$ & $\mathrm{P}=\mathbf{0 . 0 3 8}$ & $\mathrm{P}=0.289$ \\
\hline \multirow{2}{*}{$\mathrm{TN}(\%)$} & 0.018 & -0.124 & 0.091 & 0.459 & -0.509 & 0.186 & 0.313 & -0.244 & 0.124 \\
\hline & $\mathrm{P}=0.880$ & $\mathrm{P}=0.439$ & $\mathrm{P}=0.456$ & $P=0.042$ & $\mathbf{P}=\mathbf{0 . 0 2 2}$ & $\mathrm{P}=0.433$ & $P=0.046$ & $P=0.021$ & $\mathrm{P}=0.439$ \\
\hline \multirow{2}{*}{$\mathrm{TC}(\%)$} & 0.036 & -0.141 & 0.134 & 0.050 & -0.502 & 0.217 & 0.043 & -0.223 & 0.138 \\
\hline & $\mathrm{P}=0.825$ & $\mathrm{P}=0.379$ & $\mathrm{P}=0.403$ & $\mathrm{P}=0.835$ & $P=0.024$ & $\mathrm{P}=0.359$ & $\mathrm{P}=0.689$ & $P=0.036$ & $\mathrm{P}=0.197$ \\
\hline \multirow{2}{*}{$\begin{array}{l}\mathrm{NH}_{4}{ }^{+}-\mathrm{N} \\
(\mu \mathrm{g} g-1)\end{array}$} & 0.021 & -0.128 & 0.124 & 0.484 & -0.531 & 0.227 & 0.224 & -0.313 & 0.206 \\
\hline & $\mathrm{P}=0.862$ & $\mathrm{P}=0.283$ & $\mathrm{P}=0.439$ & $P=0.031$ & $P=0.016$ & $\mathrm{P}=0.336$ & $P=0.036$ & $P=0.046$ & $\mathrm{P}=0.196$ \\
\hline \multirow{2}{*}{$\begin{array}{l}\mathrm{NO}_{3}^{-}-\mathrm{N} \\
(\mu \mathrm{g} g-1)\end{array}$} & -0.025 & 0.237 & -0.128 & -0.208 & 0.752 & -0.291 & -0.089 & 0.641 & -0.223 \\
\hline & $\mathrm{P}=0.841$ & $P=0.049$ & $\mathrm{P}=0.293$ & $\mathrm{P}=0.380$ & $P=0.000$ & $\mathrm{P}=0.214$ & $\mathrm{P}=0.581$ & $P=0.000$ & $P=0.036$ \\
\hline \multirow{2}{*}{$\mathrm{GT}\left({ }^{\circ} \mathrm{C}\right)$} & 0.010 & -0.089 & 0.085 & 0.202 & -0.186 & 0.057 & 0.124 & -0.114 & 0.094 \\
\hline & $\mathrm{P}=0.948$ & $\mathrm{P}=0.581$ & $\mathrm{P}=0.492$ & $\mathrm{P}=0.394$ & $\mathrm{P}=0.433$ & $\mathrm{P}=0.812$ & $\mathrm{P}=0.439$ & $\mathrm{P}=0.289$ & $\mathrm{P}=0.383$ \\
\hline
\end{tabular}

Undisturbed, disturbed sites indicate regular transect sites and the marsh sites disturbed by waterbird colonization and human activities, respectively. Mc, TOC, TN, TC and GT indicate soil moisture, total organic carbon, total nitrogen, total carbon and ground temperature, respectively 


\section{$\mathrm{N}_{2} \mathrm{O}$ fluxes}

The dry marsh sites SD and WD showed strong $\mathrm{N}_{2} \mathrm{O}$ emissions with the mean fluxes of $13.9 \pm 2.1 \mu \mathrm{g} \mathrm{N} \mathrm{N} \mathrm{m}_{2} \mathrm{O} \mathrm{h}^{-1}$ and $20.8 \pm 6.7 \mu \mathrm{g} \mathrm{N} \mathrm{N}_{2} \mathrm{O} \mathrm{m}^{-2} \mathrm{~h}^{-1}$, respectively, whereas the mesic sites $\mathrm{SM}$ and $\mathrm{WM}$ and wet sites $\mathrm{SW}$ and $\mathrm{WW}$ presented weak $\mathrm{N}_{2} \mathrm{O}$ emissions (Fig. 2). The mean fluxes from SM $\left(11.0 \pm 2.0 \mu \mathrm{g} \mathrm{N} \mathrm{N}_{2} \mathrm{O} \mathrm{m}^{-2} \mathrm{~h}^{-1}\right)$ and $\mathrm{WM}(13.4 \pm 7.6 \mu \mathrm{g}$ $\left.\mathrm{N}_{2} \mathrm{O} \mathrm{m} \mathrm{m}^{-2} \mathrm{~h}^{-1}\right)$ were comparable to those from SW $\left(10.6 \mu \mathrm{g} \mathrm{N} \mathrm{N}_{2} \mathrm{O} \mathrm{m} \mathrm{m}^{-2} \mathrm{~h}^{-1}\right)$ and WW $\left(13.0 \pm 1.7 \mu \mathrm{g} \mathrm{N}_{2} \mathrm{O} \mathrm{m}^{-2} \mathrm{~h}^{-1}\right)$. High emission $\left(25.1 \pm 9.8 \mu \mathrm{g} \mathrm{N}_{2} \mathrm{O} \mathrm{m}^{-2} \mathrm{~h}^{-1}\right)$ occurred at the site WI, corresponding to the lowest soil moisture (Fig. 2). Overall the highest $\mathrm{N}_{2} \mathrm{O}$ fluxes (mean 49.5 $\pm 11.9 \mu \mathrm{g} \mathrm{N} \mathrm{N}_{2} \mathrm{O} \mathrm{m} \mathrm{m}^{-2} \mathrm{~h}^{-1}$ ) and slightly enhanced fluxes (mean $14.1 \pm 3.9 \mu \mathrm{g}$ $\mathrm{N}_{2} \mathrm{O} \mathrm{m}^{-2} \mathrm{~h}^{-1}$ ) occurred in poultry and waterbird active areas, respectively (Fig. 3). The landfill site LF (mean 8.9 $\pm 5.1 \mu \mathrm{g} \mathrm{N}_{2} \mathrm{O} \mathrm{m}^{-2} \mathrm{~h}^{-1}$ ) and farmland site FD (mean 5.2 $\pm 2.8 \mu \mathrm{g}$ $\mathrm{N}_{2} \mathrm{O} \mathrm{m} \mathrm{m}^{-2} \mathrm{~h}^{-1}$ ) showed relatively low $\mathrm{N}_{2} \mathrm{O}$ fluxes, comparable to the undisturbed sites (mean 8.7 $\pm 4.2 \mu \mathrm{g} \mathrm{N}_{2} \mathrm{O} \mathrm{m}^{-2} \mathrm{~h}^{-1}$ ).

The PCA analysis showed that environmental variables in the first two components explained $72.2 \%$ and $87.9 \%$ of the cumulative variance of the $\mathrm{N}_{2} \mathrm{O}$ fluxes at the undisturbed and disturbed marsh sites, respectively, and soil $\mathrm{NO}_{3}{ }^{-}-\mathrm{N}$ contents and soil moisture were the predominant factors affecting spatial variability in $\mathrm{N}_{2} \mathrm{O}$ emission (Fig. 4). The $\mathrm{N}_{2} \mathrm{O}$ fluxes showed a significant negative correlation with soil moisture at the undisturbed or disturbed marsh sites. Almost no statistically significant correlations were obtained between $\mathrm{N}_{2} \mathrm{O}$ fluxes and other environmental parameters at the undisturbed marsh sites. However, a strong positive correlation occurred between the fluxes and $\mathrm{NO}_{3}{ }^{-}-\mathrm{N}$ contents at the disturbed sites, but the weak negative correlations between the fluxes and TOC, TN and $\mathrm{NH}_{4}{ }^{+}-\mathrm{N}$ (Table 2), indicating that animal-derived $\mathrm{NO}_{3}{ }^{-}-\mathrm{N}$ input significantly enhanced $\mathrm{N}_{2} \mathrm{O}$ emissions from the SLM.

\section{$N E E$ and $E R$}

NEE between dry, mesic and wet marsh sites showed a significant difference $(\mathrm{P}<0.05)$, and the maximum mean $\mathrm{CO}_{2}$ uptake occurred at the dry sites SD and WI (-443.6 $\pm 17.0 \mathrm{mg} \mathrm{CO}_{2} \mathrm{~m}^{-2} \mathrm{~h}^{-1}$ and $-284.7 \pm 90.1 \mathrm{mg} \mathrm{CO}_{2} \mathrm{~m}^{-2} \mathrm{~h}^{-1}$, respectively) (Table 1). The marsh experienced a net gain of $\mathrm{CO}_{2}$ in the summer or in the winter (Fig. 2). Overall net $\mathrm{CO}_{2}$ emission occurred in the poultry active area $(29.1 \pm 33.2 \mathrm{mg}$ $\left.\mathrm{CO}_{2} \mathrm{~m}^{-2} \mathrm{~h}^{-1}\right)$, whereas waterbird activity area $\left(-140.0 \pm 41.9 \mathrm{mg} \mathrm{CO}_{2} \mathrm{~m}^{-2} \mathrm{~h}^{-1}\right)$, landfill $\left(-82.6 \pm 86.6 \mathrm{mg} \mathrm{CO}_{2} \mathrm{~m}^{-2} \mathrm{~h}^{-1}\right)$ and farmland (-92.2 $\left.\pm 210.9 \mathrm{mg} \mathrm{CO}_{2} \mathrm{~m}^{-2} \mathrm{~h}^{-1}\right)$ showed weak $\mathrm{CO}_{2}$ uptake compared to the non-disturbed marsh areas (Fig. 3). The marsh NEE had a strong positive correlation with soil moisture at both the undisturbed and disturbed sites, and soil moisture played a more important role in explaining the spatial variability in net $\mathrm{CO}_{2}$ fluxes (Fig. 4 and Table 2).

The mean ER rate at the dry site $\left(1106.9 \pm 109.7 \mathrm{mg} \mathrm{CO}_{2} \mathrm{~m}^{-2} \mathrm{~h}^{-1}\right)$ was greatly higher than those at the mesic $\left(674.9 \pm 210.8 \mathrm{mg} \mathrm{CO}_{2} \mathrm{~m}^{-2} \mathrm{~h}^{-1}\right)$ and wet $(694.2 \pm 420.1 \mathrm{mg}$ $\mathrm{CO}_{2} \mathrm{~m}^{-2} \mathrm{~h}^{-1}$ ) sites (Fig. $5 a$ and Table 1). Marsh ER showed a significant negative correlation with soil moisture $(\mathrm{P}<0.05)$. However, the pattern of ER appeared to follow soil temperature with a strong, positive exponential correlation $\left(\mathrm{R}^{2}=0.57, \mathrm{P}<0.05\right)$ and the $\mathrm{Q}_{10}$ value of 8.7 (Fig. 5b). Summertime photosynthesis (Pg) rates at the dry, mesic, paddy and wet sites averaged $1550.4 \pm 126.7 \mathrm{mg} \mathrm{CO} \mathrm{m}^{-2} \mathrm{~h}^{-1}, 1020.4 \pm 202.8 \mathrm{mg}$ $\mathrm{CO}_{2} \mathrm{~m}^{-2} \mathrm{~h}^{-1}, 1286.2 \pm 386.2 \mathrm{mg} \mathrm{CO}_{2} \mathrm{~m}^{-2} \mathrm{~h}^{-1}$ and $820.4 \pm 341.6 \mathrm{mg} \mathrm{CO}_{2} \mathrm{~m}^{-2} \mathrm{~h}^{-1}$, respectively, and showed a large spatial variability between the types of sites $(\mathrm{CV}=8.2 \%, 19.9 \%, 30.0 \%$ and $41.6 \%$, respectively). The Pg rates at the dry marsh 
(1550.4 $\left.\pm 126.7 \mathrm{mg} \mathrm{CO}_{2} \mathrm{~m}^{-2} \mathrm{~h}^{-1}\right)$ and paddy sites $\left(1286.2 \pm 386.2 \mathrm{mg} \mathrm{CO}_{2} \mathrm{~m}^{-2} \mathrm{~h}^{-1}\right)$ were significantly higher than those at the mesic $\left(1020.9 .4 \pm 202.8 \mathrm{mg} \mathrm{CO}_{2} \mathrm{~m}^{-2} \mathrm{~h}^{-1}\right)$ and wet marsh sites $\left(820.4 \pm 341.6 \mathrm{mg} \mathrm{CO}_{2} \mathrm{~m}^{-2} \mathrm{~h}^{-1}\right)$ (Fig. 5a).

(a)
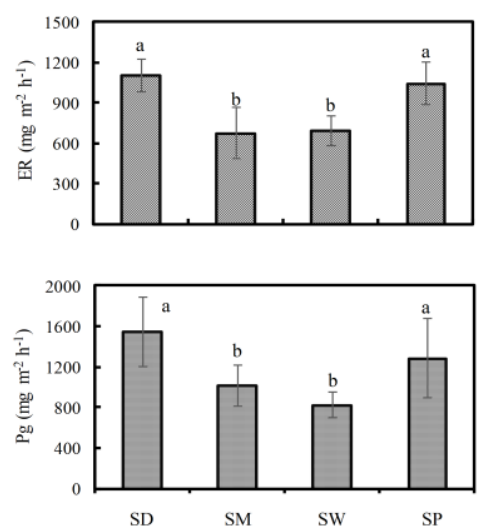

(b)
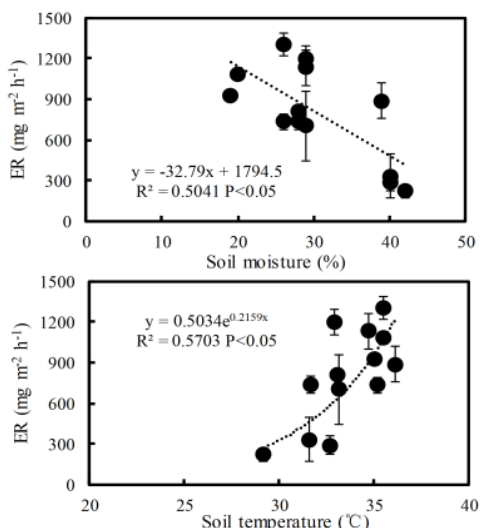

Figure 5. (a) The ecosystem respiration rates $(E R)$ and gross photosynthesis $(\mathrm{Pg})$ from the marsh transect sites during the summertime. The different lowercase letters $(a, b)$ indicate statistically significant differences between means (Fisher's LSD, $P<0.05$ ); (b) The relationship between ER and soil moisture, soil temperature at the marsh transect sites. If the overall regression is significant at $P<0.05$, regression lines and $r$ values are given

\section{Correlation between GHG fluxes and global warming potential}

The $\mathrm{N}_{2} \mathrm{O}$ and $\mathrm{CH}_{4}$ fluxes from different types of marsh sites showed a significant negative correlation, i.e. so-called "trade-off effect". The significant positive relationships occurred between $\mathrm{CH}_{4}$ flux and ER, NEE, whereas $\mathrm{N}_{2} \mathrm{O}$ fluxes showed a significant negative correlation with NEE (Fig. 6). The average $\mathrm{CH}_{4}$ and $\mathrm{N}_{2} \mathrm{O}$ fluxes are $178.8 \mu \mathrm{g} \mathrm{m}^{-2} \mathrm{~h}^{-1}(\mathrm{n}=76)$ and $15.2 \mu \mathrm{g} \mathrm{m}^{-2} \mathrm{~h}^{-1}(\mathrm{n}=76)$, respectively, and their fluxes are equivalent to $4.5 \mathrm{mg} \mathrm{CO}_{2} \mathrm{~m}^{-2} \mathrm{~h}^{-1}$ and $4.5 \mathrm{mg} \mathrm{CO}_{2} \mathrm{~m}^{-2} \mathrm{~h}^{-1}$, respectively. However, net mean $\mathrm{CO}_{2}$ flux from the marsh is $-212.6 \mathrm{mg} \mathrm{m}^{-2} \mathrm{~h}^{-1}$. A GWP-negative process strongly dominates when $\mathrm{N}_{2} \mathrm{O}, \mathrm{CH}_{4}$ and $\mathrm{CO}_{2}$ fluxes from the marsh are combined in terms of their relative GWPs. Overall the SLM is still a large "carbon sink".
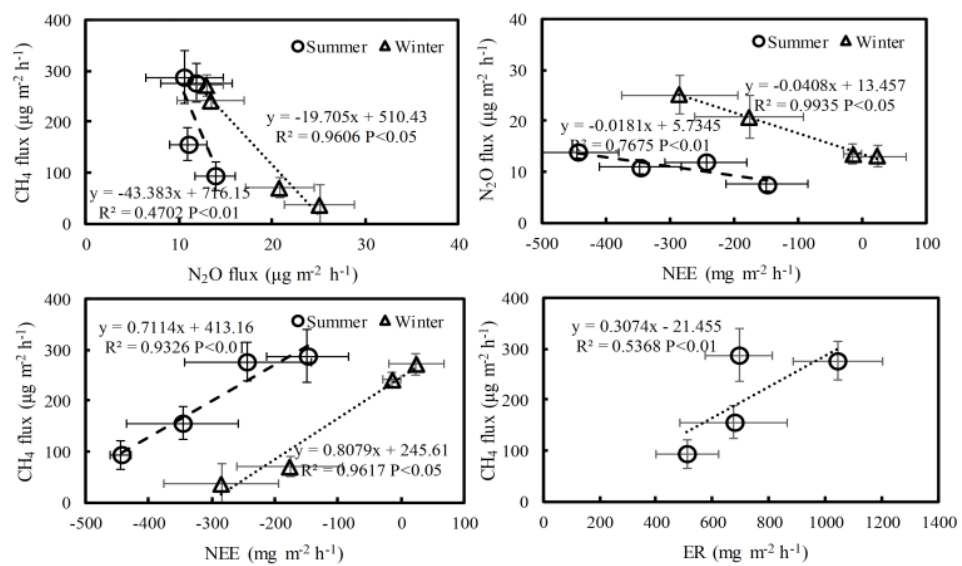

Figure 6. Correlations between $\mathrm{CH}_{4}$ flux, $\mathrm{N}_{2} \mathrm{O}$ flux, $\mathrm{NEE}$ and ER from different types of marsh sites 


\section{Discussion}

\section{Effects of soil moisture on spatial variations of GHG fluxes}

Overall our statistical analyses showed soil temperatures and soil nutrient variables were not predominant factors affecting marsh $\mathrm{CH}_{4}$ and $\mathrm{CO}_{2}$ fluxes at the undisturbed sites (Table 2). Soil moisture ( $\mathrm{Mc}$ ) had a significant difference among the sites due to the drawdown of lake level and the differences in topography, slope and hydrology, which influenced the magnitudes and variations of GHG fluxes at spatial scale (Ding et al., 2002; Song et al., 2009). Mc showed a significant positive correlation with $\mathrm{CH}_{4}$ fluxes and NEE, but a significant negative correlation with $\mathrm{N}_{2} \mathrm{O}$ (Fig. 4 and Table 2). This indicated that marsh soil moisture regulated spatial variability in marsh GHG fluxes. Soil water regime is widely recognized as the fundamental factor in regulating small-scale variation in $\mathrm{CH}_{4}$ emissions from the wetlands, given water regime can directly affect the anaerobic condition, which is necessary for $\mathrm{CH}_{4}$ production (Christensen et al., 2003; Wang et al., 2008; Wei and Wang, 2017), whereas low soil moisture make $\mathrm{O}_{2}$ diffuse into soil to oxidize $\mathrm{CH}_{4}$ into $\mathrm{CO}_{2}$ (Song and Liu, 2016; Bao et al., 2018a). Therefore the decrease in soil moisture inhibited marsh $\mathrm{CH}_{4}$ production. $\mathrm{N}_{2} \mathrm{O}$ is an intermediate product of soil nitrification and denitrification processes, and soil moisture might have an important effect on $\mathrm{N}_{2} \mathrm{O}$ production through its effects on nitrification and denitrification processes (Granli and Bockman, 1994). In this study, $\mathrm{N}_{2} \mathrm{O}$ fluxes showed a significant positive correlation with soil $\mathrm{NO}_{3}{ }^{-}-\mathrm{N}$ contents, indicating that denitrification might be the main process responsible for marsh $\mathrm{N}_{2} \mathrm{O}$ emissions. Furthermore increasing soil moisture could cause high anaerobic condition and low $\mathrm{O}_{2}$ availability, and most of $\mathrm{N}_{2} \mathrm{O}$ can be reduced to $\mathrm{N}_{2}$ via denitrification, which might cause the decrease in $\mathrm{N}_{2} \mathrm{O}$ emissions from the wetlands (Kato et al., 2011; Zhu et al., 2014b; Bao et al., 2018b). The lowering of water table could increase the volume of modestly aerated soil, thus increased the proportion of $\mathrm{N}_{2} \mathrm{O}$ production in either of nitrification and denitrification (Kato et al., 2011; Chen et al., 2013). The incomplete denitrification releases $\mathrm{N}_{2} \mathrm{O}$, which might be favorably produced in marsh soil at well-drained, aerated marsh sites (Granli and Bockman, 1994; Scaroni et al., 2014). Therefore higher $\mathrm{N}_{2} \mathrm{O}$ emissions occurred at the dry marsh sites SD, WD and WI in the SLM.

On the other hand, the decrease in soil moisture might stimulate carbon sequestration in the marsh (Fig. 2). Stronger plant photosynthesis occurred at the site SD than SM and SW (Fig. 5a), which might be due to higher vegetation coverage at the dry upland marsh (Lu and Liu, 2011; Yang et al., 2015). Soil moisture directly affected the distribution of soil microbial communities and marsh vegetation, thus influenced ecosystem respiration (Llstedt et al., 2000). Previous studies indicated that the Pg rates were the highest in dry tundra marsh with smaller differences in net $\mathrm{CO}_{2}$ exchange whereas the ER rates were limited, therefore the dry marsh showed much higher net $\mathrm{CO}_{2}$ uptake (Dagg and Lafleur, 2011). In the SLM, the decrease in soil moisture stimulated ER rates instead of limiting ER (Fig. 5b). The increase in net $\mathrm{CO}_{2}$ uptake at the dry marsh sites showed that plant photosynthesis might surpass ER with the drawdown of lake water level. Similarly, plant photosynthesis, rather than the mineralization of organic matter, played a more important role in net $\mathrm{CO}_{2}$ flux at the dry marsh site (Del Giorgio et al., 1999; Huttunen et al., 2003). Therefore plant photosynthesis might dominate $\mathrm{CO}_{2}$ exchange across air-soil interface in the SLM. In addition, a strong, positive exponential correlation between ER and soil temperature 
showed a positive feedback of ER to current warming climate. Climate warming might decrease $\mathrm{CO}_{2}$ sink through the increase in ER (Davidson and Janssens, 2006; Zhu et al., 2014a). The $\mathrm{Q}_{10}$ value of 8.7 in the SLM was much higher than the range (1.3-5.6) for different biomes of the world (Davidson and Janssens, 2006), indicating a greater temperature sensitivity to ER.

\section{Effects of animal activity and land use on GHG fluxes}

Overall the mean $\mathrm{CH}_{4}$ fluxes from waterbird and poultry active areas showed no statistical significant differences $(\mathrm{p}>0.05)$ from the undisturbed sites (Fig. 3). The fluxes from waterbird $\left(148.3 \pm 51.5 \mu \mathrm{g} \mathrm{CH} \mathrm{m}^{-2} \mathrm{~h}^{-1}\right)$ and poultry $\left(64.4 \pm 44.3 \mu \mathrm{g} \mathrm{CH}_{4} \mathrm{~m}^{-2} \mathrm{~h}^{-1}\right)$ active areas were lower than those from dairy cow feeding yards $\left(358.3 \mu \mathrm{g} \mathrm{CH}_{4} \mathrm{~m}^{-2} \mathrm{~h}^{-1}\right)$, dairy cow collecting yards $\left(429.2 \mu \mathrm{g} \mathrm{CH}_{4} \mathrm{~m}^{-2} \mathrm{~h}^{-1}\right)$, and pig loading areas $(158.3 \mu \mathrm{g}$ $\mathrm{CH}_{4} \mathrm{~m}^{-2} \mathrm{~h}^{-1}$ ) (Misselbrook et al., 2001), which might be related with low soil moisture, especially in poultry active area $(\mathrm{Mc}<30 \%$, Table S2). Lower soil moisture might greatly increase marsh $\mathrm{CH}_{4}$ consumption (Gulledge and Schimel, 1998). However, net $\mathrm{CO}_{2}$ emission occurred in the poultry active area $\left(29.1 \pm 33.2 \mathrm{mg} \mathrm{CO}_{2} \mathrm{~m}^{-2} \mathrm{~h}^{-1}\right)$, whereas waterbird activity area showed weak $\mathrm{CO}_{2}$ uptake compared to non-disturbed marsh areas, indicating that poultry activity could decrease marsh $\mathrm{CO}_{2}$ sink, even convert a marsh site from $\mathrm{CO}_{2}$ sink into a net source. Similar results also occurred in the tundra marsh disturbed by marine animal activities (Zhu et al., 2014a).

The $\mathrm{N}_{2} \mathrm{O}$ fluxes from poultry (mean $49.5 \pm 11.9 \mu \mathrm{g} \mathrm{N} \mathrm{N}_{2} \mathrm{O} \mathrm{m}^{-2} \mathrm{~h}^{-1}$ ) and waterbird (mean $14.1 \pm 3.9 \mu \mathrm{g} \mathrm{N}_{2} \mathrm{O} \mathrm{m}^{-2} \mathrm{~h}^{-1}$ ) active areas were comparable to or even greater than those from the farm yards used by livestock (11.8-27.5 $\mu \mathrm{g} \mathrm{N}_{2} \mathrm{O} \mathrm{m}^{-2} \mathrm{~h}^{-1}$ ) (Misselbrook et al., 2001), and from some temperate extensive pastures or rangelands (0-26.6 $\mu \mathrm{g}$ $\mathrm{N}_{2} \mathrm{O} \mathrm{m}^{-2} \mathrm{~h}^{-1}$ ) (Phillips et al., 2007), and those from heavily fertilized agricultural systems and tropical forests $\left(23.6-83.3 \mu \mathrm{g} \mathrm{N}_{2} \mathrm{O} \mathrm{m}^{-2} \mathrm{~h}^{-1}\right)$, which are the two largest $\mathrm{N}_{2} \mathrm{O}$ sources worldwide (Perez et al., 2001). Similar results also occurred in tundra marsh sites disturbed by seabird activities (13.3-57.4 $\mu \mathrm{g} \mathrm{N} \mathrm{N}_{2} \mathrm{O} \mathrm{m}^{-2} \mathrm{~h}^{-1}$ ) (Zhu et al., 2012, 2013). The high $\mathrm{N}_{2} \mathrm{O}$ emissions from poultry or waterbird active areas might be modulated by soil physical and chemical processes associated with animal activities: continuous $\mathrm{N}$ input from animal excreta and animal tramp (Zhu et al., 2012). Significantly elevated $\mathrm{NO}_{3}{ }^{-}-\mathrm{N}$ concentrations occurred in animal-disturbed marsh soils as compared with undisturbed soils (Table S2). A strong positive correlation between $\mathrm{N}_{2} \mathrm{O}$ fluxes and soil $\mathrm{NO}_{3}{ }^{-}-\mathrm{N}$ contents confirmed that animal-derived $\mathrm{NO}_{3}{ }^{-}-\mathrm{N}$ input had an important effect on spatial variability in $\mathrm{N}_{2} \mathrm{O}$ fluxes (Fig. 4 and Table 2). Therefore, animal activity and the deposition of their excreta significantly enhanced $\mathrm{N}_{2} \mathrm{O}$ emissions in the SLM.

During the conversion of the marsh into paddy fields, human tillage and the rice plants with well-developed aerenchyma might lead to the increase in $\mathrm{CH}_{4}$ emission (Cai et al., 1997). The plants with well-developed aerenchyma are important in determining net $\mathrm{CH}_{4}$ fluxes from some wetlands (Bass et al., 2014; Bao et al., 2018b). However, net $\mathrm{CH}_{4}, \mathrm{~N}_{2} \mathrm{O}$ and $\mathrm{CO}_{2}$ fluxes from agricultural field site $\mathrm{FD}$ were comparable to the undisturbed sites (Fig. 3), indicating that the conversion of the marsh into agricultural fields did not significantly change GHG emissions. Landfill gas is mainly composed of $\mathrm{CH}_{4}$ and $\mathrm{CO}_{2}$, which is generated during decomposition of the solid waste (Sharma et al., 2011). The landfill did not change $\mathrm{CH}_{4}$ and $\mathrm{N}_{2} \mathrm{O}$ fluxes, and slightly decreased $\mathrm{CO}_{2}$ uptake compared to non-disturbed marsh areas (Fig. 3). GHG fluxes from the landfill were lower than those reported from sanitary landfills (Bogner et al., 1995; Rinne et al., 2005; Kormi et al., 2017). Generally landfill GHG emission estimates are highly 
uncertain because factors influencing gas emission and mitigation are site specific (Boeckx et al., 1996). Landfill GHG emissions can range over six orders of magnitudes (Lando et al., 2017). The ambient and soil moisture had an important effect on GHG production from the landfill (Rinne et al., 2005). During the study period, very high soil moisture (68\%-73\%, Table S2) might stimulate $\mathrm{CH}_{4}$ and $\mathrm{CO}_{2}$ emissions, but decrease $\mathrm{N}_{2} \mathrm{O}$ production from the landfill (Fig. 3).

In summary, correlation analyses revealed that GHG fluxes from the disturbed marsh sites were involved in more complicated factors than from undisturbed sites (Table 2). Significant positive correlations $(\mathrm{p}<0.05)$ between net $\mathrm{CH}_{4}$ and $\mathrm{CO}_{2}$ fluxes and soil moisture, soil nutrients indicated that their fluxes might be modulated by soil physical and chemical processes associated with animal activities (Zhu et al., 2012, 2013). Negative correlations were generally observed between $\mathrm{N}_{2} \mathrm{O}$ emissions and soil moisture, nutrient variables TOC, TC, TN and $\mathrm{NH}_{4}{ }^{+}$at the disturbed sites and all the combined sites (Fig. 4 and Table 2), which was different from some previous studies (Chen et al., 2011; Sun et al., 2014). One possible reason was related to the interaction of vegetation and microorganism (nitrifiers and denitrifiers) during $\mathrm{N}_{2} \mathrm{O}$ production (Sun et al., 2014). $\mathrm{N}_{2} \mathrm{O}$ production might be partly inhibited as the available $\mathrm{N}$ was significantly competed by both vegetations and microorganisms in Artemisia lavandulaefolia DC and Artemisia scoparia waldst community (Lu and Liu, 2011; Yang et al., 2015), which partly contributed to the difference in $\mathrm{N}_{2} \mathrm{O}$ emissions at spatial scale. Overall the PCA analysis showed that soil moisture was the predominant factor affecting spatial variability in marsh GHGs fluxes from the undisturbed and disturbed sites in the SLM (Fig. 4). This preliminary study only provided short summertime or wintertime GHG fluxes from agricultural field or landfill in the SLM, and effects of animal activities and land use on marsh GHG emissions need to be further confirmed in the future.

\section{Implication of marsh GHG evaluation}

The SLM, as a typical natural freshwater wetland in the Middle-Lower Yangtze Plain, is involved in effects of complicated factors including environmental variables, human activities and waterbird colonization ( $\mathrm{Lu}$ and Liu, 2011; Yang et al., 2015; Zhang et al., 2015). The coefficients of variance (CV) of $\mathrm{CH}_{4}, \mathrm{~N}_{2} \mathrm{O}$ and $\mathrm{CO}_{2}$ fluxes were relatively small $(<100 \%)$ within the same type of sites. However, their fluxes showed significant differences among the sites, indicating that to assess the regional GHG budget precisely, measurements should be designed at fine scales and environmental heterogeneity should be considered in the marsh. In addition, the study area has a temperate monsoon climate with an evident distinction in precipitation between rainy and dry seasons. This could lead to soil moisture changes, dry-wet alternation and wetland extent dynamics, and cause the "trade-off effect" of $\mathrm{N}_{2} \mathrm{O}$ and $\mathrm{CH}_{4}$ fluxes and carbon sequestration in the marsh (Cai et al., 1997; Ding and Cai, 2007). Effects of soil moisture changes on "trade-off effect" of $\mathrm{N}_{2} \mathrm{O}$ and $\mathrm{CH}_{4}$ fluxes need to be used for accurate evaluation of net GWP in the SLM. In summary, there still remains a large uncertainty regarding the evaluation of GHG budgets in the SLM. The GHG budget evaluation for the SLM and other similar MLYP wetlands should be involved in soil water regimes, waterbird colonization and human-induced influences. 


\section{Conclusions}

We revealed effects of soil moisture, animal activities and land use on GHG fluxes from the SLM based upon in situ flux measurements. Overall $\mathrm{CH}_{4}$ emissions from the dry marsh sites were much lower than those from wet or mesic sites, vice versa for $\mathrm{N}_{2} \mathrm{O}$ emissions and NEE. Soil moisture was the predominant factor controlling the spatial variability in marsh $\mathrm{CH}_{4}$ and $\mathrm{N}_{2} \mathrm{O}$ fluxes and $\mathrm{NEE}$ at undisturbed sites. Correlation analyses revealed that GHG fluxes from the disturbed marsh sites were involved in more complicated factors than from undisturbed sites. The mean $\mathrm{CH}_{4}$ fluxes from waterbird and poultry active areas showed no statistically significant differences ( $p>0.05$ ) from the undisturbed sites, but animal activities increased $\mathrm{N}_{2} \mathrm{O}$ emissions, decreased marsh $\mathrm{CO}_{2}$ sink, even convert into a net $\mathrm{CO}_{2}$ source. The conversion of the marsh into agricultural field and landfill did not significantly change GHG emissions compared to non-disturbed marsh areas. To assess the regional GHG budget precisely, measurements should be designed at fine scales and environmental heterogeneity should be considered in the marsh. This study only provided short summertime and wintertime GHG fluxes, and long-term and high-frequency observations are needed to accurately quantify GHG budgets in the SLM. Continued investigations into the dynamics of GHG fluxes as well as mechanisms of GHG production in natural wetland, with an emphasis on temporal variation are essential in the future.

Acknowledgments. This work was supported by the National Natural Science Foundation of China (Grant No. 41576181; 41776190) and the Strategic Priority Research Program of Chinese Academy of Science (No. XDB40010200). The authors would like to thank three anonymous reviewers for their helpful comments.

\section{REFERENCES}

[1] Bao, T., Zhu, R., Li, X., Ye, W., Cheng, X. (2018a): Effects of multiple environmental variables on tundra ecosystem respiration in maritime Antarctica. - Scientific Reports 8(1): 12336.

[2] Bao, T., Zhu, R., Wang, P., Ye, W., Ma, D., Xu, H. (2018b): Potential effects of ultraviolet radiation reduction on tundra nitrous oxide and methane fluxes in maritime Antarctica. Scientific Reports 8(1): 3716.

[3] Bass, A. M., O'Grady, D., Leblanc, M., Tweed, S., Nelson, P. N., Bird, M. I. (2014): Carbon Dioxide and Methane Emissions from a Wet-Dry Tropical Floodplain in Northern Australia. - Wetlands 34: 619-627.

[4] Boeckx, P., Van Cleemput, O., Villaralvo, I. D. A. (1996): Methane emission from a landfill and the methane oxidising capacity of its covering soil. - Soil Biology and Biochemistry 28: 1397-1405.

[5] Bogner, J., Spokas, K., Burton, E., Sweeney, R., Corona, V. (1995): Landfills as atmospheric methane sources and sinks. - Chemosphere 31: 4119-4130.

[6] Cai, Z. C., Xing, G. X., Yan, X. Y., Xu, H., Tsuruta, H., Yagi, K., Minami, K. (1997): Methane and nitrous oxide emissions from rice paddy fields as affected by nitrogen fertilisers and water management. - Plant and Soil 196: 7-14.

[7] Chen, H., Yao, S. P., Wu, N., Wang, Y. F., Luo, P., Tian, J. Q., Gao, Y. H., Sun, G. (2008): Determinants influencing seasonal variations of methane emissions from alpine wetlands in Zoige Plateau and their implications. - Journal of Geophysical Research: Atmosphere 113 (D12). 
[8] Chen, H., Wu, N., Wang, Y. F., Gao, Y. H., Peng, C. H. (2011): Methane fluxes from alpine wetlands of Zoige Plateau in relation to water regime and vegetation under two scales. Water Air and Soil Pollution 217: 173-183.

[9] Chen, Q. Q., Zhu, R. B., Xu, H. (2013): Spatial and temporal variations in $\mathrm{CO}_{2}, \mathrm{CH}_{4}$ and $\mathrm{N}_{2} \mathrm{O}$ concentration in Ny-alesund, Svalbard. - Advance in Polar Science 25: 150-160.

[10] Christensen, T. R., Panikov, N., Mastepanov, M. (2003): Biotic controls on $\mathrm{CO}_{2}$ and $\mathrm{CH}_{4}$ exchange in wetlands-a closed environment study. - Biogeochemistry 64: 337-354.

[11] Dagg, J., Lafleur, P. (2011): Vegetation community, foliar nitrogen, and temperature effects on tundra $\mathrm{CO}_{2}$ exchange across a soil moisture gradient. - Arctic Antarctic and Alpine Research 43: 189-197.

[12] Davidson, E. A., Janssens, I. A. (2006): Temperature sensitivity of soil carbon decomposition and feedbacks to climate change. - Nature 440: 165-173.

[13] Del Giorgio, P. A., Cole, J. J., Caraco, N. F., Peters, R. H. (1999): Linking planktonic biomass and metabolism to net gas fluxes in northern temperate lakes. - Ecology 80: 1422-1431.

[14] Ding, W. X., Cai, Z. C., Tsuruta, H. (2002): Effects of standing water depth on methane emissions from freshwater marshes in northeast China. - Atmospheric Environment 38: 181188.

[15] Ding, W. X., Cai, Z. C., Tsuruta, H. (2004): Diel variation in methane emissions from the stands of Carex lasiocarpa and Deyeuxia angustifolia in a cool temperate freshwater marsh. Atmospheric Environment 38: 181-188.

[16] Ding, W. X., Cai, Z. C. (2007): Methane emission from natural wetlands in China: Summary of years 1995-2004 studies. - Pedosphere 17: 475-486.

[17] Duan, X. N., Wang, X. K., Mu, Y. J., Ouyang, Z. Y. (2005): Seasonal and diurnal variations in methane emissions from Wuliangsu Lake in arid regions of China. - Atmospheric Environment 39: 4479-4487.

[18] Fang, J. Y., Wang, Z. H., Zhao, S. Q., Li, Y. K., Tang, Z. Y., Yu, D., Ni, L. Y., Liu, H. Z., Xie, P., Da, L. G., Li, Z. Q., Zheng, C. Y. (2006): Biodiversity changes in the lakes of the Central Yangtze. - Frontiers in Ecology and the Environment 4: 369-377.

[19] Fox, A. D., Hearn, R. D., Cao, L., Cong, P. H., Wang, X., Zhang, Y., Dou, S. T., Shao, Z. F., Barter, M., Rees, E. C. (2013): Preliminary observations of diurnal feeding patterns of Swan Geese Anser cygnoides using two different habitats at Shengjin Lake, Anhui Province, China. - Wildfowl 58: 20-30.

[20] Granli, T., Bockman, O. C. (1994): Nitrogen oxide from agriculture. - Norwegian Journal of Agricultural Sciences 12: 7-127.

[21] Gulledge, J., Schimel, J. P. (1998): Moisture control over atmospheric $\mathrm{CH}_{4}$ consumption and $\mathrm{CO}_{2}$ production in diverse Alaskan soils. - Soil Biology and Biochemistry 30: 1127-1132.

[22] Hu, Q. W., Cai, J. Y., Yao, B., Wu, Q., Wang, Y. Q., Wu, X. L. (2016): Plant-mediated methane and nitrous oxide fluxes from a Carex meadow in Poyang Lake during drawdown periods. - Plant and Soil 400: 367-380.

[23] Hutchinson, G. L., Mosier, A. R. (1981): Improved soil cover method for field measurement of nitrous oxide fluxes. - Soil Science Society of America Journal 45: 311-316.

[24] Huttunen, J. T., Alm, J., Liikanen, J. S., Larmola, T., Hannar, T., Sivola, J., Martikainen, P. J. (2003): Fluxes of methane, carbon dioxide and nitrous oxide in boreal lakes and potential anthropogenic effects on the aquatic greenhouse gas emissions. - Chemosphere 52: 609-621.

[25] Jiang, H. X., Xu, W. B., Qian, F. W., Chu, G. Z. (2007): Impact of habitat evolvement and human disturbance on wintering water birds in Shengjin Lake of Anhui Province, China. Chinese Journal of Applied Ecology 18: 1832-1836.

[26] Johansson, T., Malmer, N., Crill, P. M., Mastepanov, M., Christensen, T. R. (2006): Decal vegetation changes in a northern peatland, greenhouse gas fluxes and net radiative forcing. Global Change Biology 12: 2352-2369.

[27] Jungkunst, H. F., Fiedler, S. (2007): Latitudinal differentiated water table control of $\mathrm{CO}_{2}, \mathrm{CH}_{4}$ and $\mathrm{N}_{2} \mathrm{O}$ fluxes from hydromorphic soils: feedbacks to climate change. - Global Change Biology 13: 2668-2683. 
[28] Kato, T., Hirota, M., Tang, Y. H., Wada, E. (2011): Spatial variability of $\mathrm{CH}_{4}$ and $\mathrm{N}_{2} \mathrm{O}$ fluxes in alpine ecosystems on the Qinghai-Tibetan Plateau. - Atmospheric Environment 45: 56325639.

[29] Kirschke, S., Bousquet, P., Ciais, P. (2013): Three decades of global methane sources and sinks. - Nature Geoscience 6: 813-823.

[30] Kormi, T., Ali, N. B. H., Abichou, T., Green, R. (2017): Estimation of landfill methane emissions using stochastic search methods. - Atmospheric Pollution Research 8: 597-605.

[31] Lando, A. T., Nakayama, H., Shimaoka, T. (2017): Application of portable gas detector in point and scanning method to estimate spatial distribution of methane emission in landfill. Waste Management 59: 255-266.

[32] Llstedt, U., Nordgren, A., Maimer, A. (2000): Optimum soil water for soil respiration before and after amendment with glucose in humid tropical acrisols and a boreal mor layer. - Soil Biology and Biochemistry 32: 1591-1599.

[33] Lu, Z. M., Liu, L. (2011): Investigation and analysis of Present Wetland Environmental Situation of Shengjin Lake. - Journal of Chizhou College 6: 80-83. (in Chinese).

[34] Marani, L., Alvala, P. C. (2007): Methane emissions from lakes and floodplains in Pantanal, Brazil. - Atmospheric Environment 41: 1627-1633.

[35] Martikainen, P., Nykänen, H., Crill, P., Silvola, J. (1993): Effect of a lowered water table on nitrous oxide fluxes from northern peatlands. - Nature 366: 51-53.

[36] Misselbrook, T. H., Webb, J., Chadwick, D. R., Ellis, S., Pain, B. F. (2001): Gaseous emissions from outdoor concrete yards used by livestock. - Atmospheric Environment 35: 5331-5338.

[37] Perez, T., Trumbore, S. E., Tyler, S. C., Matson, P. A., Ortiz-Monasterio, I., Rahn, T., Griffith, D. W. T. (2001): Identifying the agricultural imprint on the global $\mathrm{N}_{2} \mathrm{O}$ budget using stable isotopes. - Journal of Geophysical Research 106: 9869-9878.

[38] Phillips, F. A., Leuning, R., Baigenta, R., Kelly, K. B., Denmead, O. T. (2007): Nitrous oxide flux measurements from an intensively managed irrigated pasture using micrometeorological techniques. - Agricultural and Forest Meteorology 143: 92-105.

[39] Post, W. M., Emanuel, W. R., Zinke, P. J., Stangenberger, A. G. (1982): Soil carbon pool and world life zones. - Nature 298: 156-159.

[40] Ravishankara, A. R., Daniel, J. S., Portmann, R. W. (2009): Nitrous oxide $\left(\mathrm{N}_{2} \mathrm{O}\right)$ : the dominant ozone-depleting substance emitted in the 21st century. - Science 326: 123-125.

[41] Rinne, J., Pihlatie, M., Lohila, A., Thum, T., Aurela, M., Tuovinen, J. P., Laurila, T., Vesala, T. (2005): Nitrous oxide emissions from a municipal landfill. - Environmental Science and Technology 39: 7790-7793.

[42] Scaroni, A. E., Ye, S. Y., Lindau, C. W., Nyman, J. A. (2014): Nitrous Oxide Emissions from Soils in Louisiana's Atchafalaya River Basin. - Wetlands 34: 545-554.

[43] Sharma, S. K., Choudhury, A., Sarkar, P. (2011): Greenhouse gas inventory estimates for India. - Current Science 101: 405-415.

[44] Song, C. C., Xu, X. F., Tian, H. Q., Wang, Y. Y. (2009): Ecosystem-atmosphere exchange of $\mathrm{CH}_{4}$ and $\mathrm{N}_{2} \mathrm{O}$ and ecosystem respiration in wetlands in the Sanjiang Plain, Northeastern China. - Global Change Biology 15: 692-705.

[45] Song, W. M., Wang, H., Wang, G. S., Chen, L. T., Jin, Z. N., Zhuang, Q. L., He, J. S. (2015): $\mathrm{CH}_{4}$ emissions from an alpine wetland on the Tibetan Plateau: neglected but vital contribution of non-growing season. - Journal of Geophysical Research: Biogeoscience 120: 1475-1490.

[46] Ström, L., Christensen, T. R. (2007): Below ground carbon turnover and greenhouse gas exchanges in a sub-arctic wetland. - Soil Biology and Biochemistry 39: 1689-1698.

[47] Sun, Z. G., Wang, L. L., Mou, X. J., Jiang, H. H., Sun, W. L. (2014): Spatial and temporal variations of nitrous oxide flux between coastal marsh and the atmosphere in the Yellow River estuary of China. - Environmental Science and Pollution Research 21: 419-433.

[48] Wang, H. J., Lu, J. W., Wang, W. D., Yang, L. Y., Yin, C. Q. (2006): Methane fluxes from the littoral zone of hypereutrophic Tai Lake, China. - Journal of Geophysical Research: Atmosphere 111 (D17). 
[49] Wang, W. Q., Zeng, C. S., Tong, C. (2008): Methane Production and Oxidation Capacities of Soil from the Reed Marsh of the Minjiang River Estuary. - Wetland Science 6: 60-68.

[50] Wang, Z. P., Song, Y., Gulledge, J., Yu, Q., Liu, H. S., Han, X. G. (2009): China's grazed temperate grasslands are a net source of atmospheric methane. - Atmospheric Environment 43: 2148-2153.

[51] Wang, Z. M., Wu, J. G., Madden, M., Mao, D. H. (2012): China's wetlands: conservation plans and policy impacts. - Ambio 41: 782-786.

[52] Wei, D., Xu, R., Tarchen, T., Dai, D. X., Wang, Y. S., Wang, Y. H. (2015): Revisiting the role of $\mathrm{CH}_{4}$ emissions from alpine wetlands on the Tibetan Plateau: evidence from two in situ measurements at 4758 and $4320 \mathrm{~m}$ above sea level. - Journal of Geophysical Research: Biogeoscience 120: 1741-1750.

[53] Wei, D., Wang, X. D. (2017): Uncertainty and dynamics of natural wetland $\mathrm{CH}_{4}$ release in China: Research status and priorities. - Atmospheric Environment 154: 95-105.

[54] Xing, Y. P., Xie, P., Yang, H., Ni, L. Y., Wang, Y. S., Rong, K. W. (2005): Methane and carbon dioxide fluxes from a shallow hypereutrophic subtropical lake in China. Atmospheric Environment 39: 5532-5540.

[55] Xu, L. L., Xu, W. B., Zhou, Z. Z., Sun, Q. Y. (2008): Flora and vegetation in Shengjin Lake. - Journal of Wuhan Botanical Research 27: 264-270. (in Chinese).

[56] Yang, S. W., Dong, B., Liu, L. P., Sun, L., Sheng, S. W., Wang, Q., Peng, W. J., Wang, X., Zhang, Z. F., Zhao, J. (2015): Research on vegetation coverage change in Shengjin Lake Wetland of Anhui Province. - Wetlands 35: 677-682.

[57] Zhang, Y., Jia, Q., Prins, H. H. T. (2015): Effect of conservation efforts and ecological variables on waterbird population sizes in wetlands of the Yangtze River. - Scientific Reports 5: 17136.

[58] Zhou, B., Zhou, L. Z., Chen, J. Y., Cheng, Y. Q., Xu, W. B. (2010): Diurnal time activity budgets of wintering hooded cranes (Grus monacha) in Shengjin Lake, China. - Waterbirds 33: $110-115$.

[59] Zhu, R. B., Liu, Y. S., Ma, E. D., Sun, J. J., Xu, H., Sun, L. G. (2009): Nutrient compositions and potential greenhouse gas production in penguin guano, ornithogenic soils and seal colony soils in coastal Antarctica. - Antarctic Science 21: 427-438.

[60] Zhu, R. B., Chen, Q. Q., Ding, W., Xu, H. (2012): Impact of seabird activity on nitrous oxide and methane fluxes from High Arctic tundra in Svalbard, Norway. - Journal of Geophysical Research 117: G04015.

[61] Zhu, R. B., Liu, Y. S., Xu, H., Ma, D. W., Jiang, S. (2013): Marine animals significantly increase tundra $\mathrm{N}_{2} \mathrm{O}$ and $\mathrm{CH}_{4}$ emissions in maritime Antarctica. - Journal of Geophysical Research: Biogeoscience 118: 1773-1792.

[62] Zhu, R. B., Bao, T., Wang, Q., Xu, H., Liu, Y. S. (2014a): Summertime $\mathrm{CO}_{2}$ fluxes and ecosystem respiration from marine animal colony tundra in maritime Antarctica. Atmospheric Environment 98: 190-201.

[63] Zhu, R. B., Ma, D. W., Xu, H. (2014b): Summertime $\mathrm{N}_{2} \mathrm{O}, \mathrm{CH}_{4}$ and $\mathrm{CO}_{2}$ exchanges from a tundra marsh and an upland tundra in maritime Antarctica. - Atmospheric Environment 83: 269-281.

\section{APPENDIX}

Electronic Appendix: The detailed information about investigation sites, experimental design and soil physiochemical properties at all the stations were summarized in the Appendix. 